medRxiv preprint doi: https://doi.org/10.1101/2022.01.14.22269271; this version posted January $14,2022$. The copyright holder for this preprint (which was not certified by peer review) is the author/funder, who has granted medRxiv a license to display the preprint in It is made available under a CC-BY-NC-ND 4.0 International license .

\title{
Quality of Care for Children Under Five with Malaria Using IMCI Approach at Public Health Centre: Literature Review
}

\author{
Orpa Diana Suek 1,2 Moses Glorino Rumambo Pandin 3 \\ ${ }_{1}$ Doctoral Nursing Program, Faculty of Nursing, Airlangga University, \\ ${ }_{2}$ Nursing School of Health Polytechnic of Kupang \\ ${ }_{3}$ Faculty of Humanities, Airlangga University \\ correspondence:dianasuek@yahoo.com
}

\begin{abstract}
Integrated Management of Childhood Illness is one of the strategies in health care services for infants and children under five at primary health care facilities. Children with fever in high malaria endemic areas must have a blood test done to check whether the children have malaria or not. IMCI is one of the interventions recommended by WHO to screen and also ensure that children receive proper initial treatment at first-level health facilities. This article aims to discuss the quality of care for children under five with malaria using IMCI approach. This is a systematic review by searching 4 databases including Scopus, Web of Science, SAGE and Proquest. Health care services for children under five with an integrated management of childhood illness are intended to provide immediate and appropriate treatment. The guideline for treating children under five with malaria using IMCI approach is very helpful for nurses both in assessing, classifying, treating/curing and making decisions for pre-referral measures for severe cases. Several factors to support quality of care are trained officers, supervision and procurement of essential medicines, RDT and malaria microscopy. Enforcement of the right diagnosis will improve the quality of life of children and prevent death in children under five.
\end{abstract}

Keywords: IMCI, Malaria, Children under five 
medRxiv preprint doi: https://doi.org/10.1101/2022.01.14.22269271; this version posted January $14,2022$. The copyright holder for this preprint (which was not certified by peer review) is the author/funder, who has granted medRxiv a license to display the preprint in It is made available under a CC-BY-NC-ND 4.0 International license .

\section{INTRODUCTION}

Various efforts are continuously made in order to reduce the mortality rate of newborns, infants and children under five. The health development goals stated in the Sustainable Development Goals (SDG's) are to ensure a healthy life and promote well-being for all people at all ages, including infants and children under five who are prone to illness. One of the targets is ending infant and under-five mortality which can be prevented in 2030 by reducing the Neonatal Mortality Rate to at least 12 per 1000 Live Births and Children Under Five Mortality Rate to 25 per 1000 Live Births (Hussein, S., \& Farhood, H. 2019; WHO, 2019).

Integrated Management of Childhood Illness (IMCI) has been introduced by WHO for 30 years ago with the aim at improving the health status of children. Currently, IMCI strategy is being performed all over the world including Indonesia. IMCI is an integrated strategy to improve children's health, which is associated with a number of significant health problems as the main cause of morbidity and mortality such as pneumonia, diarrhoea, malnutrition, measles, malaria. Children brought to health care facilities are often found to be suffering from more than one unwell condition, making a single diagnosis impossible. Children need a combination therapy for successful treatment. Khan, MS, et al (2020) conducted a survey related to the implementation of IMCI and found that children require a combination therapy to achieve a successful treatment outcome.

Children under five with fever are screened with IMCI chart in a public health centre (PHC). Officers will carry out assessments, classifications, measures/treatments, counselling and decide on return visits (Ministry of Health, 2019; Suek, OD, \& Ina, A. 2019). The patients with fever are screened for three diseases including malaria, measles and dengue hemorrhagic fever. In high malaria endemic areas, every sick child must be tested for malaria (Ministry of Health, 2021). 
Malaria is an infectious disease caused by a parasite called Plasmodium that can infects humans through the bite of a female Anopheles mosquito that can attack anyone regardless of age, including children (WHO, 2019; Dittrich, S et al, 2020). Indonesia is a malaria endemic area, especially coastal areas. There are 5 (five) malaria endemic provinces in Indonesia. The implementation of IMCI needs to be developed. This intervention makes it easier for health workers to find cases of malaria in children and provide appropriate and rational treatment.

\section{OBJECTIVE}

The objective of this paper is to explore quality of care for children under five with malaria using IMCI approach at public health centres covering assessment, classification and treatment.

\section{METHOD}

The design of this study is a literature review. The literature used in this study consists of research articles related to quality of care for children under five with malaria using IMCI approach. These articles were published in reputable international journals. The literature was searched in Scopus, Web of Science, SAGE and Proquest databases. The keywords were IMCI, quality of care and malaria. The literature had to meet the inclusion criteria where the population should be children under five with fever or malaria. In addition, descriptive analysis was added.

Table 1.1

Inclusion and exclusion criteria with PICOS

\begin{tabular}{lll}
\hline \multicolumn{1}{c}{ Criteria } & \multicolumn{1}{c}{ Inclusion } & \multicolumn{1}{c}{ Exclusion } \\
\hline Population & Under five with fever/malaria & Children less than 2 months \\
\hline Intervention & IMCI & Not using IMCI \\
\hline Comparison & There is no comparison & There are no criteria of conclusion \\
\hline Outcome & $\begin{array}{l}\text { Assessment, classification and } \\
\text { treatment based on IMCI chart }\end{array}$ & Not compatible with IMCI \\
\hline Study Type & $\begin{array}{l}\text { Case study, Randomized Controlled } \\
\text { Trial, A quasy experimental, cross }\end{array}$ & Systematic or literature review, \\
& $\begin{array}{l}\text { sectional, Controlled Clinical Trial, } \\
\text { action research, mix method }\end{array}$ & \\
& &
\end{tabular}


medRxiv preprint doi: https://doi.org/10.1101/2022.01.14.22269271; this version posted January $14,2022$. The copyright holder for this preprint (which was not certified by peer review) is the author/funder, who has granted medRxiv a license to display the preprint in It is made available under a CC-BY-NC-ND 4.0 International license .

\begin{tabular}{lll}
\hline Publication type & Peer reviewed original studies & Non peer reviewed studies \\
\hline Publication years & 2019-2021 & Pre 2019 \\
\hline language & English & Other than English \\
\hline
\end{tabular}

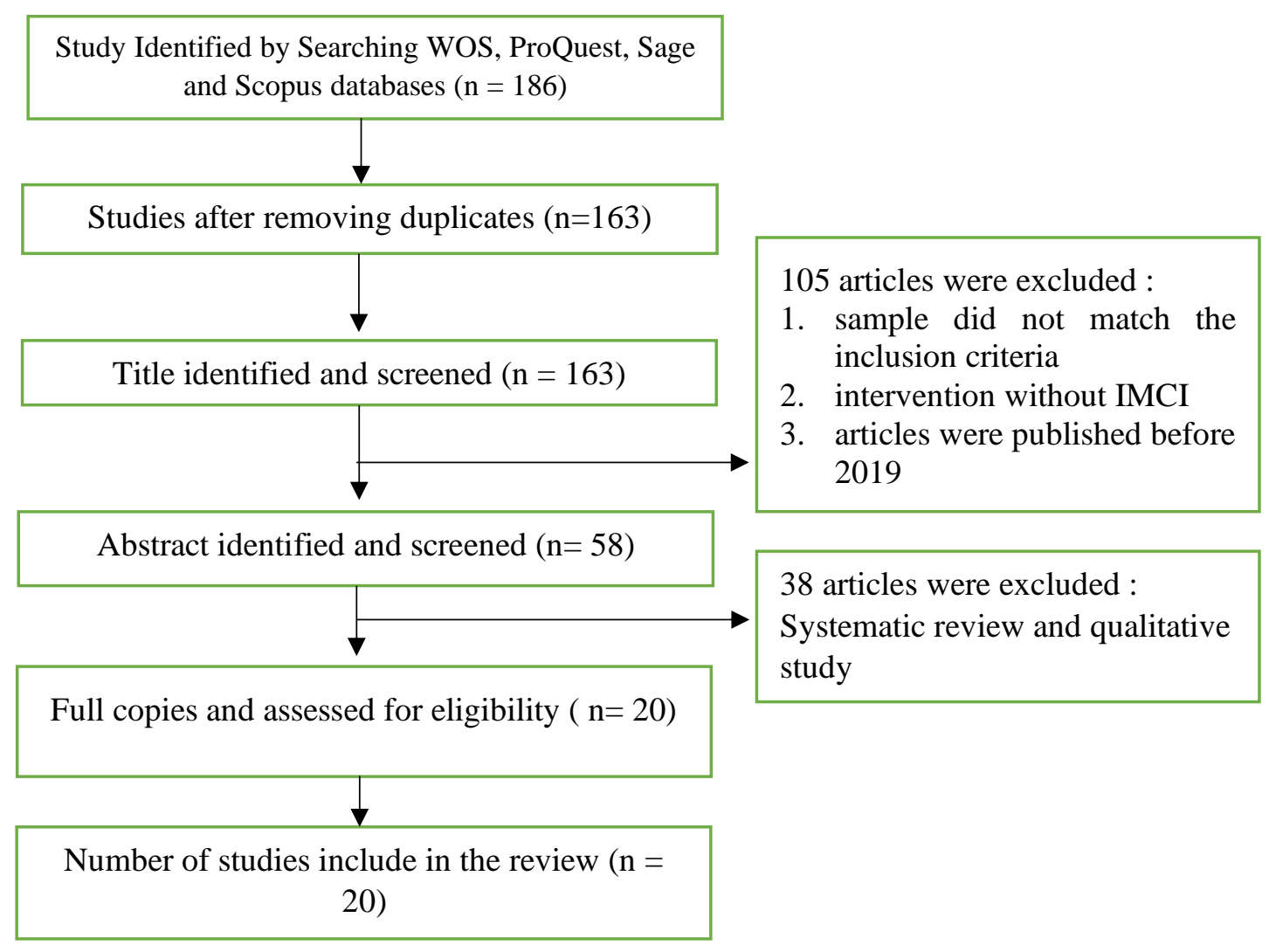

Figure 1. Article Selection Flow (PRISMA 2020)

\section{RESULTS}

Table 1.2.

\section{Distribution of intervention using IMCI to improve quality of care for children under five with malaria}

Researchers, Year

Rozelle, JW et al (2021)

\section{Result}

The presence of health assistants and the implementation of IMCI to children with malaria diagnosed $50 \%$ by confirmation of RDT and microscopic examination and 51\% treatment of malaria in children under five in rural areas made the percentage of malaria diagnoses confirmed by microscopy or RDT increased from $71 \%$ before the program to $95 \%$ in 2020.

Abdulrahman, A., \& Saleem, The classification of sick children with IMCI guidelines has AM (2019) a significant effect due to a reduction of inappropriate use of antibiotics in children with fever 
medRxiv preprint doi: https://doi.org/10.1101/2022.01.14.22269271; this version posted January $14,2022$. The copyright holder for this preprint (which was not certified by peer review) is the author/funder, who has granted medRxiv a license to display the preprint in It is made available under a CC-BY-NC-ND 4.0 International license .

\begin{tabular}{|c|c|}
\hline $\begin{array}{l}\text { Nyaoke, BA, Mureithi, MW, \& } \\
\text { Beynon, C. (2019) }\end{array}$ & $\begin{array}{l}\text { Prescription of antimalarial medicines despite negative } \\
\text { microscopic results was found in } 44 \text { children }(12.9 \%) \text {, with } \\
48 \text { mortality rate }(14.1 \%)\end{array}$ \\
\hline $\begin{array}{l}\text { Clarke-Deelder, E., Shapira, G., } \\
\text { Samaha, H., Fritsche, GB, \& } \\
\text { Fink, G. (2019) }\end{array}$ & $\begin{array}{l}\text { lack of adherence to diagnostic and treatment protocols. } 332 \\
(28 \%) \text { of } 1180 \text { children under five who were observed, had } \\
\text { signs of severe febrile disease, and less than } 15 \% \text { of patients } \\
\text { were referred to a higher health care facility. }\end{array}$ \\
\hline $\begin{array}{l}\text { Getachew, T., Abebe, SM, } \\
\text { Yitayal, M., Persson, L. ., \& } \\
\text { Berhanu, D. (2020) }\end{array}$ & $\begin{array}{l}\text { Body temperature of patients ( } 92 \%) \text { were checked. It was } \\
\text { found that } 3 \% \text { of children with fever were referred or treated, } \\
\text { and } 60 \% \text { of them got antibiotics. } 51 \% \text { of children with } \\
\text { malaria were assessed for screening with IMCI strategy and } \\
4 \% \text { of them were screened for general danger signs. }\end{array}$ \\
\hline $\begin{array}{l}\text { Hartley, MA, Hofmann, N., } \\
\text { Keitel, K., Kagoro, F., Antunes } \\
\text { Moniz, C., Mlaganile, T., \& } \\
\text { D'Acremont, V. (2020) }\end{array}$ & $\begin{array}{l}\text { According to WHO Guidelines for Integrated Management } \\
\text { of childhood Illness, it was recommended that antimalarial } \\
\text { treatment was performed when the results of standard mRDT } \\
\text { were released. Only a quarter of } 2,801 \text { outpatients with IMCI } \\
\text { had parasites undetectable by standard mRDT. }\end{array}$ \\
\hline
\end{tabular}

\section{DISCUSSION}

The strategy for implementing IMCI includes promotive, preventive, curative and rehabilitative activities. IMCI services are focused on case management by looking at clinical signs and empirical therapy that can be carried out by doctors, nurses, midwives, and other health workers in primary services such as polyclinics, health centers, clinics, and hospitals. According to IMCI Handbook (Kemenkes, 2019), the process includes assessment and classification, which are interrelated and inseparable. IMCI must be performed comprehensively and simultaneously, especially in a developing country like Indonesia. This strategy strongly contributes to achieve children's health status. Several articles claimed that IMCI was proven effectively to improve the quality of care for children, increase health care cost savings, and possibly reduce child mortality in developing countries.

Fever in children is one of the typical signs of infectious disease in children, where fever is said to be a general clinical sign of a disease contract. A study in malaria-endemic countries found that $71.4 \%$ of children with fever were caused by malaria Nkoka, O., Chuang, TW, \& Chen, YH, 2019). In high malaria endemic areas, it is mandatory to check temperature and examine blood samples both by RDT and microscopic. IMCI is an evidence-based strategy that is widely adopted to prove testing and treatment for children 
medRxiv preprint doi: https://doi.org/10.1101/2022.01.14.22269271; this version posted January $14,2022$. The copyright holder for this preprint (which was not certified by peer review) is the author/funder, who has granted medRxiv a license to display the preprint in It is made available under a CC-BY-NC-ND 4.0 International license .

with malaria, by improving access and quality of care specially to enforce diagnosis and treatment of malaria in children (Rozelle, et al. 2021). Balanza, N., et al, 2020 stated that "fever is a common problem in children. Most episodes of fever are caused by selflimiting infections, but a small number of children will develop life-threatening infections. Each infection has a symptom threshold, and other clinical symptoms can distinguish a sick child from asymptomatic or so-called progenic fever in malaria cases (Hartley, MA et al, 2020).

The protocol for a comprehensive and consistent integrated management of childhood illness (IMCI) has been used to promote accurate assessment and classification of childhood diseases, ensure appropriate combination treatment, strengthen caregiver counselling and accelerate referrals to reduce child mortality and morbidity. Success in implementing IMCI must be supported by training on IMCI standardization, weekly supportive supervision, availability of essential medicines and supporting infrastructure for IMCI services such as chart books and recording formulas.

In malaria endemic countries, malaria is suspected mainly by fever. WHO recommends early malaria diagnosis (within 24 hours of symptom onset) to prevent the occurrence of severe malaria. IMCI screening in febrile children has helped early diagnosis and treatment of uncomplicated malaria, thereby reducing the effects of severe malaria.

\section{CONCLUSION}

IMCI is one of the appropriate interventions for screening, diagnostic tests and appropriate actions to children under five with malaria. Children are given antimalarial therapy if only supported by the results of RDT or malaria microscopy.

\section{INTEREST CONFLICT}

There is no conflict of interest in writing this literature review. 
medRxiv preprint doi: https://doi.org/10.1101/2022.01.14.22269271; this version posted January $14,2022$. The copyright holder for this preprint (which was not certified by peer review) is the author/funder, who has granted medRxiv a license to display the preprint in It is made available under a CC-BY-NC-ND 4.0 International license .

\section{BIBLIOGRAPHY}

1. Abdulrahman, A., \& Saleem, AM (2019). Implementation of Integrated Management of Childhood Illness Strategy's in Al Hadbaa Primary Health Care Center in Mosul City. Annals of the College of Medicine, Mosul, 41(1), 75-80.

2. Abayneh, M., Gebremedhin, T., Dellie, E., Tsehay, CT, \& Atnafu, A. (2020). Improving the Assessment and Classification of Sick Children according to the Integrated Management of Childhood Illness (IMCI) Protocol at Sanja Primary Hospital, Northwest Ethiopia: A Pre-Post Interventional Study. International Journal of Pediatrics, 2020.

3. Asante, SK, \& Mensah, KA (2021). Quality care management of febrile illnesses among children under 5 years in Atwima Kwanwoma district in the Ashanti region of Ghana (Doctoral dissertation).

4. Boyce, SP, Nyangara, F., \& Kamunyori, J. (2019). A mixed-methods quasiexperimental evaluation of a mobile health application and quality of care in the integrated community case management program in Malawi. Journal of global health, 9(1).

5. Balanza, N., Erice, C., Ngai, M., Varo, R., Kain, KC, \& Bassat, Q. (2020). Host-based prognostic biomarkers to improve risk stratification and outcome of febrile children in low-and middle-income countries. Frontiers in Pediatrics, 8.

6. Cañas, JAO, Sierra, AMG, Mora, YYP, Oliveros, DSR, Galvis, . JA, Flórez, LJH, \& Rueda, JSP (2021). Clinical Assessment of Integrated Management of Childhood Illnesses (IMCI) Given by Professionals Trained Between 2012 and 2015 in Colombia: A Cross-Sectional Study.

7. Clarke-Deelder, E., Shapira, G., Samaha, H., Fritsche, GB, \& Fink, G. (2019). Quality of care for children with severe disease in the Democratic Republic of the Congo. BMC public health, 19(1), 1-12.

8. Dalrymple, U., Cameron, E., Arambepola, R., Battle, KE, Chestnutt, EG, Keddie, SH, \& Geting, PW (2019). The contribution of non-malarial febrile illness co-infections to Plasmodium falciparum case counts in health facilities in sub-Saharan Africa. Malaria journal, 18(1), 1-12.

9. Dittrich, S., Lamy, M., Acharya, S., Thu, HK, Datta, R., Blacksell, SD, Hein, PS, Mercado, CEG, Ding, XC, \& Chebbi, A. (2020). Diagnosing malaria and other febrile illnesses during the COVID-19 pandemic. In The Lancet Global Health (Vol. 8, Issue 7, pp. e879-e880). Elsevier Ltd. https://doi.org/10.1016/S2214-109X(20)30210-2

10. Getachew, T., Abebe, SM, Yitayal, M., Persson, L. ., \& Berhanu, D. (2020). Assessing the quality of care in sick child services at health facilities in Ethiopia. BMC Health Services Research, 20(1), 1-12.

11. Hernández-Escolar, J., Moreno, CB, \& Mondragon-Bohórquez, S. (2021). Validation of an instrument to evaluate the community component of the integrated care strategy for prevalent childhood diseases (IMCI). Enfermeria Global, 20(1), 183-192. https://doi.org/10.6018/eglobal.422001

12. Hartley, MA, Hofmann, N., Keitel, K., Kagoro, F., Antunes Moniz, C., Mlaganile, T., ... \& D'Acremont, V. (2020). Clinical relevance of low-density Plasmodium falciparum parasitemia in untreated febrile children: A cohort study. PLoS medicine, 17(9), e1003318. 
13. Humphreys, D., Kalyango, JN, \& Alfvén, T. (2021). The impact of equity factors on receipt of timely appropriate care for children with suspected malaria in eastern Uganda. BMC Public Health, 21(1), 1-9.

14. Isezuo, KO, Onankpa, BO, Adamu, A., Jiya, FB, \& Amodu-Sanni, M. (2020). SocioDemographic Factors Associated with Late Presentation and Outcome of Febrile Children Admitted in a Tertiary Facility in North-Western Nigeria: A Comparative Study. Int J Pediatrics Res, 6, 063.

15. Isezuo, KO, Onankpa, BO, Adamu, A., Jiya, FB, \& Amodu-Sanni, M. (2020). Delayed Presentation and Outcome of Febrile Children Admitted in a Tertiary Facility in Sokoto, North-Western Nigeria: A Case-Control Study. Int J Pediatrics Res, 6, 063.

16. Jegede, A., Willey, B., Hamade, P., Oshiname, F., Chandramohan, D., Ajayi, I., \& Webster, J. (2020). Evaluation of a capacity building intervention on malaria treatment for under-fives in rural health facilities in Niger State, Nigeria. Malaria journal, 19(1), 1-11.

17. Keitel, K., Samaka, J., Masimba, J., Temba, H., Said, Z., Kagoro, F., ... \& D'Acremont, V. (2019). Safety and efficacy of C-reactive protein-guided antibiotic use to treat acute respiratory infections in Tanzanian children: a planned subgroup analysis of a randomized controlled noninferiority trial evaluating a novel electronic clinical decision algorithm (ePOCT). Clinical Infectious Diseases, 69(11), 19261934.

18. Khan, MS, Miah, R., Hussain, T., Moosa, S., Quaium, MA, \& Rahman, A. (2020). A Survey on Implementation of Integrated Management of Childhood Illness (IMCI) in Northeastern Part of Bangladesh. Article in American Journal of Medicine and Medical Sciences, 2020(9), 682-689. https://doi.org/10.5923/j.ajmms.20201009.12

19. Kiemde, F., Bonko, MDA, Tahita, MC, Mens, PF, Tinto, H., Schallig, HD, \& van Hensbroek, MB (2019). Algorithms for sequential interpretation of a malaria rapid diagnostic test detecting two different targets of Plasmodium species to improve diagnostic accuracy in a rural setting (Nanoro, Burkina Faso). Plos one, 14(2), e0211801.

20. Kilov, K., Hildenwall, H., Dube, A., Zadutsa, B., Banda, L., Langton, J., ... \& King, C. (2021). Integrated Management of Childhood Illnesses (IMCI): a mixed-methods study on implementation, knowledge and resource availability in Malawi. BMJ pediatric open, 5(1).

21. Moyo, SJ, Manyahi, J., Blomberg, B., Tellevik, MG, Masoud, NS, Aboud, S., ... \& Langeland, N. (2020). Bacteraemia, malaria, and case fatality among children hospitalized with fever in Dar es Salaam, Tanzania. Frontiers in microbiology, 11, 2118.

22. Nkoka, O., Chuang, TW, \& Chen, YH (2019). Multilevel analysis of factors associated with treatment-seeking behaviors among caregivers with febrile children in Malawi. The American journal of tropical medicine and hygiene, 100(6), 1454.

23. Nyaoke, BA, Mureithi, MW, \& Beynon, C. (2019). Factors associated with treatment type of non-malarial febrile illnesses in under-fives at Kenyatta National Hospital in Nairobi, Kenya. Plos one, 14(6), e0217980.

24. Rozelle, JW, Korvah, J., Wiah, O., Kraemer, J., Hirschhorn, LR, Price, MR, ... \& Panjabi, R. (2021). Improvements in malaria testing and treatment after a national community health worker program in rural Liberia. Journal of Global Health Reports, 5, e2021073. 
medRxiv preprint doi: https://doi.org/10.1101/2022.01.14.22269271; this version posted January $14,2022$. The copyright holder for this preprint (which was not certified by peer review) is the author/funder, who has granted medRxiv a license to display the preprint in

It is made available under a CC-BY-NC-ND 4.0 International license .

25. Suek, OD, \& Ina, A. (2019). Implementation of Integrated Management of Sick Toddlers (MTBS) in Kupang City. Proceedings of the National Sanitation National Committee, 318-325.

26. Traoré, SA, Somda, SM, Kiendrébéogo, JA, Kouldiati, JL, Robyn, PJ, Hien, H., \& Méda, N. (2019). Factors associated with adherence to the Integrated Management of Childhood Illness (IMCI) guidelines for under-five years' old care in Burkina Faso primary health care facilities. bioRxiv, 510099 .

27. Van De Maat, J., De Santis, O., Luwanda, L., Tan, R., \& Keitel, K. (2021). Primary Care Case Management of Febrile Children: Insights From the ePOCT Routine Care Cohort in Dar es Salaam, Tanzania. Frontiers in pediatrics, 9, 465.

28. WHO (World Health Organization) (2019). Key Facts for Children: reducing mortality.URLs:https://www.who.int/newsroom/fact-sheets/detail/children-

reducing-mortality 